\title{
Digital Smartness: Rethinking Communities and Citizenship in the Face of 'Smart' Technology
}

\author{
Florian Schneider \\ Chinese Department, Leiden University Institute for Area Studies, Vrieshof \\ 2, Room 104a, P.O. Box 9515, 2300 RA Leiden, The Netherlands \\ f.a.schneider@hum.leidenuniv.nl
}

\begin{abstract}
This introduction to the Asiascape: Digital Asia special issue on 'smart communities' discusses how new technologies have created a paradigm of 'smartness' that informs how innovators, entrepreneurs, policy makers, and administrators imagine sociality in urban spaces. This is visible in plans for turning Singapore, Hong Kong, or Taipei into 'smart cities', and countries such as India, Japan, and South Korea are similarly rolling out initiatives that promise to revamp urban life across the region. Such 'solutionist' attempts to address the complexities of contemporary social life through technology cleverly fuse surveillance techniques, capitalist structures, free labour practices, and neoliberal governance to create urban utopias of safety, convenience, and community. We have asked the contributors to this special issue to explore what people do, through and with digital technologies, as they establish, claim, contest, and alter various social relations in the name of 'smart community', and this article introduces and discusses their results.
\end{abstract}

\section{Keywords}

smart cities - community - governance - urban planning - digital technology surveillance - capitalism - Asia

The smart community has become the new digital utopia, the new frontier for imagining and producing sociality in a digital world. The homes we inhabit, the spaces through which we move, and the interactions in which we engage are increasingly defined by technologies that promise to make our lives more 
convenient, our interactions more efficient, and our societies more secureall under the banner of 'smartness'. Advances in digital technology since the early 2000 s have convinced many designers, entrepreneurs, and policy makers that new forms of social, political, and economic engineering are on the horizon, enabled by automation and robotics, platforms and gadgets, algorithms and databases, social computing and blockchains, facial recognition and biometrics, and wireless networking protocols and radio-frequency identification (RFID). Most recently, as $5 \mathrm{G}$ technology promises to radically increase the bandwidth of data transmissions and as storage of 'big data' becomes more affordable, as increases in computing power allow ever more advanced analytical processes and as the much-evoked 'internet of things' is becoming a reality, companies and governments are dreaming up 'smart' ways to revolutionize how our societies work.

These ambitions are evocatively captured by the idea of a 'smart city' (for a discussion, see Townsend 2013). A smart city is an urban place that has been designated by its elites as a site where state and business actors collaboratively deploy advanced technology to create optimized spatial and social arrangements in the service of innovative capitalist value extraction. These practices, which rely heavily on data collection and analysis, are then explained and justified as improvements in personal convenience, economic welfare, communal vitality, and environmental sustainability (for critiques, see Greenfield 2013; Hollands 2008).

The consultancy group Frost \& Sullivan (2013) has spelled out an instructive vision of 'smart cities'. In this view, cities will 'evolve into clusters of smart communities' (p. 4), enabling citizens to 'live in a safe community with sufficient access to all service' (p. 11). The market research company envisions that this entails innovation across numerous domains, all of which are designated as 'smart': 'smart energy, smart technology, smart infrastructure, smart mobility, smart building, smart healthcare, smart governance and smart education, and smart citizens' (ibid.: 2). Importantly, Frost \& Sullivan promises its clients a renewed push towards neoliberal governance that goes well beyond what the public-private 'governance' collaborations of the 1980 s or 1990 s entailed (see Donahue \& Zeckhauser 2008; Stoker 1998). In this 'new business model', private enterprises are no longer merely contractors; they 'participate in the governance of cities and become a supplementary part of the government' (Frost \& Sullivan 2013: 13). The marketeers do not fail to repeatedly remind their audience of how much money is bound to be involved in these endeavours, projecting that by 2020 the global 'smart city' market will be worth USD 1.565 trillion (ibid.). This is roughly the size of the entire yearly national income of a country such as Russia or South Korea. 
The commercial and administrative potential of the 'smart community' idea has not been lost on actors in Asia. Although the idea of a smart city has been around since the beginning of the twenty-first century, wedded closely to ideas about the 'knowledge economy' (see also Hollands 2008), recent technological developments have given 'smartification' projects a renewed push, and this is particularly visible in Asian cities, where urban planners have been experimenting with ways to leverage this alluring paradigm. In Singapore, the 'Smart Nation' plan promises to 'make Citizens' lives better', 'create opportunities for Businesses', and 'build a better home and community' through technology (Smart Nation and Digital Government Office 2019). In Taipei, the municipal government 'offers itself as a platform for opening up the city as a living lab', where a 'constant injection of innovative energy' is meant to prompt government institutions and private enterprises to experiment with everything from smart trash cans and smart streetlights to smart health services and smart eldercare to open government and civic tech (ТРMO 2016). Similarly, Hong Kong's government promises to 'enable businesses' in ways that will 'transform the city into a living lab and test bed for development', all in the hope of making 'people happier, healthier, smarter and more prosperous, and the city greener, cleaner, more livable, sustainable, resilient and competitive' (Innovation and Technology Bureau 2017). Cities in Japan have likewise rolled out smart city initiatives (for an overview, see DeWit 2013), and municipal governments in South Korea are either updating their infrastructure with smart tech or are building new smart districts from scratch, such as Seoul's satellite town New Songdo (see Greenfield 2013: 70; Townsend 2013: 25). Meanwhile, the Indian government has made smart cities a national policy priority and has designated 100 cities to drive its 'transform-nation' through 'technology that leads to Smart outcomes' (MOUD 2015).

Throughout their efforts to 'smartify' society, advocates appeal to the idea that technology can improve community. We would be well-advised not to take their use of the concept at face value. As Zane Kripe points out in this issue, in the social sciences the idea of community comes with a great deal of baggage. The term often evokes warm feelings of belonging, a cosy sense of solidarity, and positive associations with egalitarian interactions, which risk obscuring that the actors who make, maintain, and manage communities (or claim to do so) rely on existing social and material relations that are by no means innocent. Although activities in the service of 'community' may at times be well meaning, they are also frequently self-interested, tied to hierarchies and privileges, and informed by quests for power and profit.

These issues are amplified in contexts that appeal to 'digital communities' or 'smart communities', where solidarity and belonging are projected onto 
seemingly new forms of group formation. Digital technology enables actors to connect themselves and others in geographically dispersed webs of social ties, many of which no longer rely on face-to-face interactions to work. We could say that such linkages constitute potential ties-ties that can be created and disrupted, weakened or strengthened, utilized or ignored as actors within interconnected clusters of people go about their affairs. 'Smartness' might then best be understood as the ability to recognize patterns of digitally enabled connections and leverage them to achieve specific ends, for instance, in government, industry, or commerce.

The ways in which powerful actors then try to legitimate their 'smartification' agendas through appeals to community sentiments deserves close scrutiny across a number of dimensions. The smart paradigm is not just a powerful heuristic device for those who know how to wield it; it is a full-blown epistemology: a way of knowing digital society and of knowing how to recalibrate digital society. This way of knowing also provides a way of disciplining the subjects of the 'smart community', by defining what a 'smart' citizen should be ('efficient', 'creative', 'engaged', and so forth), what a community should look like ('resilient', 'connected', 'sustainable', etc.), and what should matter in contemporary urban spaces ('energy', 'infrastructure', 'services', and so on). Through its clever fusion of solutionist discourses and social practices (see Morozov 2013), many of which have their origin in Silicon Valley ideology (Turner 2008), this epistemology creates the perfect soil in which contemporary surveillance capitalism can then grow (Zuboff 2019). Those who do not fit the bill of the smart citizen are 'switched off' (Castells 2009) and excluded from circuits of power and capital. Those who are able to participate become quickly entangled in, and ultimately dependent on, the conveniences that smart tech offers. As Zuboff (2019: 11) writes: 'Our dependency is at the heart of the commercial surveillance project, in which our felt needs for effective life vie against the inclination to resist its bold incursions.' Schneier (2012) similarly warns that users of digital technology are increasingly pushed to 'pledge allegiance to the united states of convenience', and he goes as far as calling this dynamic 'digital feudalism'.

The practices that are now unfolding in Asia are intriguing examples of how diverse actors go about their activities in a world full of smart gadgets that promise digital conveniences and new forms of sociality. Asian contexts offer valuable lessons about what happens when the increasingly popular discourse about 'smart' technology and 'smart' community is reworked and employed in diverse local contexts. What do people do, through and with digital technologies, as they establish, claim, contest, and alter various social relations in the name of a 'smart community'? To answer this question, we have asked the contributors to this special issue of Asiascape:Digital Asia to reflect on the 
meaning of 'community' in contexts that use, or claim to use, 'smart' tech. Our contributors first came together at the conference Rethinking Communities in the Age of the Digital, organized by Brill Academic Publishing, the International Institute for Asian Studies (IIAS), the Leiden Asia Centre, and Leiden University on 29 May 2018, and the articles in this special issue are the outcome of discussions and reflections from that event.

In the first contribution, 'Making Community Work: Constructing Singapore's Start-up Community', Zane Kripe examines how ideas about community played into a crucial industry sector in Singapore: the technology start-up scene. Through social events and networking activities at tech conferences, the entrepreneurs who are involved in that scene try hard to build 'community' for themselves, their partners, and their customers. At the same time, they try to inspire a sense of 'community' through their products, which are frequently platforms that run on 'community-generated' content, that is: the free labour of users. Kripe's in-depth ethnographic work highlights how actors in Singapore's much-evoked knowledge economy claim the community label for themselves and others, but how those practices ironically also create exclusion, vulnerability, and even exploitation. Kripe reminds us that this is precisely why 'community' is best viewed as 'an emic concept for those involved in the production of web technologies'.

In a similar vein, Anoma van der Veere, in 'The Technological Utopia: Mimamori Care and Family Separation in Japan', treats concepts such as community, family, care, and safety as emic to Japanese discussions about 'smart' living, though he takes a different empirical approach: by analyzing policy documents and news reports, van der Veere reveals the discursive moves and epistemic models that characterize efforts to save traditional ideals about the extended family in the face of demographic shifts. Confronted with Japan's rapidly ageing society, actors in the Abe Shinzo administration and their ideological allies in the public are praising smart surveillance and robotics tech as harbingers of a conservative utopia. Yet as these actors fantasize about innovations in areas such as elder care and labour markets, they are perpetuating — and possibly accelerating - precisely the kind of socio-economic contradictions that have been 'exacerbating separation among families' for some time.

Keeping the focus on Japan, Deirdre Sneep, in 'Cell Phone City: Reinventing Tokyo's Urban Space for Social Use', examines how smartphones have transformed interactions in Tokyo's urban spaces. Japan is a fascinating case for such exploration, because the tech industry there had been experimenting with mobile internet applications long before companies in the United States and Europe rolled out the first smartphones. As a country of early adopters, Japan then also features intriguing discourses and practices that involve 
mobile technology use in urban spaces. As Sneep shows through her detailed participatory observations and spatial analyses, smartphone use has recalibrated how people move through and behave in Tokyo's public spaces, for instance, creating 'mobile phone hubs' that allow pedestrians to exit the flow of foot traffic and congregate in near-anonymity with other tech users while connecting to their social networks at a distance.

These practices create overlapping spheres of (para-social) communion that define how people experience urban space in contemporary Japan. Importantly, behaviour of this sort is not actually that new: as Sneep reminds us, the smartphone merely updates how people navigate complex urban spaces, in Japan and elsewhere. 'Smart' tech now enhances and augments older practices, for instance, when users use their devices to 'obscure' themselves from others in public settings, a practice that might previously have involved newspapers or books. In the 'cellphone city', smartphones allow users to create bubbles of digitally augmented private spaces or windows into social interactions that are taking place at a distance, and this changes where we might need to look for 'community' attachments.

Concluding our special issue on 'smart community', 'Digital India's Smart Transform-Nation: Enabling or Discouraging a “Chatur Citizenry”?' by Michelle Ruiz Andrade provides a reality check on how smart city planning has played out in a specific Indian city: Chandigarh, a well-known example of modernist urban planning. Today, the municipal government is again engaged in a largescale urban planning exercise, this time within the framework of India's national push to create smart cities across the sub-continent. Ruiz's fieldwork reveals that much of this exercise is haphazard, contradictory, and ultimately ill-suited for addressing the challenges faced by Chandigarh's inhabitants. Enamoured with smart parking, smart traffic, and other projects that address middleclass concerns, the city's urban planners are leaving behind more vulnerable citizens, who are increasingly demanding a 'right to the city'. Post-colonial studies frequently interpret the activities of 'switched-off' subaltern actors as signs of resistance, and in this case specifically as examples of street-smart citizenship, something that Datta (2018) has called 'chatur citizenry', a term that refers to clever bottom-up resourcefulness. Ruiz remains sceptical that elevating subaltern everyday resistance to the level of an alternate 'smartness' is helpful in challenging the elites that are pushing for automated, smart cities. Instead, she stresses that a truly citizen-centred approach to Indian urbanism should place civic rights and material needs at its core.

All these contributions to the special issue of Asiascape: Digital Asia show that aspirations, imaginations, and knowledge about 'smart' technology shape community ideals and social practices in Asian urban environments. They 
offer insightful studies on how elites co-opt the idea of 'community' to push their solutionist paradigm for urban and social development, and they prompt us to question whether the contradictions that unfold in the process are really as novel as these digitally accelerated elites and their discourses make them out to be. This, then, is a potential call to action: our contributors intervene in public discussions about 'smart communities' and ask us to look beyond the 'shiny new thing' to see who benefits from digital innovations and who is sidelined, ignored, or switched off.

\section{Works Cited}

Castells, Manuel (2009), Communication Power. Oxford: Oxford University Press.

Datta, Ayona (2018), 'The Digital Turn in Postcolonial Urbanism: Smart Citizenship in the Making of India's 100 Smart Cities'. Transactions of the Institute of British Geographers, 43, 405-419.

DeWit, Andrew (2013), 'Japan's Rollout of Smart Cities: What Role for the Citizens?' Asia-Pacific Journal, 11(24/2), 1-12. Retrieved 8 July 2019 from https:/apjjf.org/ -Andrew-DeWit/4131/article.pdf.

Donahue, John D. \& Zeckhauser, Richard J. (2008), 'Public-Private Collaboration'. In Moran, Michael, Rein, Martin \& Goodin, Robert E. (ed.), The Oxford Handbook of Public Policy. Oxford: Oxford University Press, 496-525.

Frost \& Sullivan (2013), 'Strategic Opportunity Analysis of the Global Smart City Market'. Retrieved 8 July 2019 from https://dsimg.ubm-us.net/envelope/153353/295 862/1391029790_strategic_opportunity.pdf.

Greenfield, Adam (2013), Against the Smart City. New York: Do Projects. (Kindle ed.). Hollands, Robert G. (2008), 'Will the Real Smart City Please Stand Up? Intelligent, Progressive or Entrepreneurial?' City, 12(3), 303-320.

Innovation and Technology Bureau (2017), 'Hong Kong Smart City Blueprint'. SmartCity.gov.hk, retrieved 8 July from https://www.smartcity.gov.hk/blueprint/ HongKongSmartCityBlueprint_e-flipbook_EN/mobile/index.html\#p=1/.

Morozov, Evgeny (2013), To Save Everything, Click Here: Technology, Solutionism, and the Urge to Fix Problems that Don't Exist. New York: Penguin Press. (Kindle ed.). MOUD (Ministry of Urban Development) (2015), Smart City Mission Transform-nation: Mission Statement \& Guidelines. New Delhi: Government of India Ministry of Housing and Urban Affairs. Retrieved 8 July 2019 from http://smartcities.gov.in/ upload/uploadfiles/files/SmartCityGuidelines(1).pdf.

Schneier, Bruce (2012, November 26), 'When It Comes to Security, We're Back to Feudalism'. Wired, retrieved 8 July 2019 from https://www.schneier.com/essays/ archives/2012/11/when_it_comes_to_sec.html. 
Smart Nation and Digital Government Office (2019), 'Transforming Singapore Through Technology'. SmartNation.sg, retrieved 8 July 2019 from https://www.smartnation. sg/why-Smart-Nation.

Stoker, Gerry (1998), 'Governance as Theory: Five Propositions'. International Social Science Journal, 50(150), 17-28.

Townsend, Antony M. (2013), Smart Cities: Big Data, Civic Hackers, and the Quest for a New Utopia. New York: W.W. Norton.

трмо (2016), Smart Taipei Brochure. Taipei: Taipei Project Management Office, retrieved 8 July 2019 from https://smartcity.taipei/posts/26/.

Turner, Fred (2008), From Counterculture to Cyberculture: Stewart Brand, the Whole Earth Network, and the Rise of Digital Utopianism. Chicago: University of Chicago Press.

Zuboff, Shoshana (2019), The Age of Surveillance Capitalism: The Fight for a Human Future at a New Frontier of Power. New York: PublicAffairs. 